\title{
CIRCADIAN CHANGES OF THE MELATONIN CONCENTRATION IN THE BLOOD OF PREGNANT COWS AND CALVES
}

\author{
W. F. SKRZYPCZAK \\ Department of Animal Physiology. University of Agriculture, \\ Szczecin. Poland \\ Received February 18, 1998 \\ Accepted August 19. 1998
}

\begin{abstract}
Skrzypczak W. F.: Circadian Changes of the Melatonin Concentration in the Blood of Pregnant Con's and Calves. Acta vet. Brno 1998. 67: 153-158.

It has been shown in numerous studies on animals and man that melatonin production is rhythmic and light-dependent. Since relevant literature concerning cattle is missing, and having in mind scientific and practical importance of such knowledge, we decided to investigate circadian changes of the melatonin level in the blood of cows and calves.

The experiment was carried out on pregnant cows and 2.5-month-old calves. Before and during the experiment animals were kept under the same light - dark regime (LD 10:14). The blood samples were drawn ninefold from the external jugular vein over a period of 24 hours. at 15:00. 18:00. 21:00, 24:00, 3:00, 6:00, 9:00, 12:00 and 15:00 h. Melatonin was determined by the radioimmunoassay (RIA) method. The findings were analysed using the Duncan`s D test.

Highly significant differences ( $P<0.01$ ) were found between the level of melatonin in the light and the dark phase, both in cows and calves. The blood concentration of this hormone in calves in both phases was significantly lower $(\mathrm{P}<0.01)$ when compared to cows. Also the overnight profile of the melatonin production was different in cows and calves: this is an evidence of changes in the melatonin synthesis and release in the dark phase with age.
\end{abstract}

Pregnant cows, calies, melatonin, circadian changes

From among all known biological rhythms the circadian rhythms play a major role in adaptation of organism to the conditions of surroundings. The pineal gland constitutes an important part of the mechanism that is capable of measuring out time by an organism. It acts in a synchronizing manner on the rhythmicity of different physiological processes by producing and regularly bringing about the release of melatonin. It is generally supposed that the main centre controlling the activity of the pineal gland and maintaining the rhythm of the secretion of melatonin is the nucleus suprachiasmaticus situated in the anterior part of the hypothalamus (Cymborowski et al. 1969; Deguchi 1979; Hasegawa et al. 1980; Klein 1979: Reiter 1991; Wurtman 1985).

Melatonin is synthesized by parenchymal cells of the pineal body that are capable of catching tryptophan. a precursor for indolic compounds, out from the circulation system. It shows a short biological half-life in blood (10-40 minutes), high systemic clearance and relatively low volume of distribution (Binkley 1979; Klein et al. 1996; Mallo et al. 1990; Reiter 1991: Waldhauser et al. 1984).

It has been shown in numerous studies on animals and humans that biosynthesis of melatonin takes a course according to the circadian rhythm that is light-dependent and generated by endogenic biological clock. The production of this hormone does not depend

\footnotetext{
Address for Correspondence:

Prof. Wieslaw F. Shrzopczak

Department of Animal Physiolog!

University of Agriculture. Dohtora Judyma St. No 6.

71-466 Szezecin. Poland
}

Phone: $+0+8091+5+1521$ ext. 369

Fux: $\quad+0+8091+5+16+2$ 
on the mode of life of a given species (nocturnal, diurnal, mixed) and is always highest at night or in the dark phase of the artificial light cycle. A very distinct circadian rhythm of the melatonin level was found in many animal species, with a low level during a day and higher one at night (Berthelot et al. 1990; Hedlund et al. 1977; Hougton et al. 1993; Klein et al. 1996: Nowak et al. 1990; Reiter 1991; Waldhauser et al. 1983; Waldhauser et al. 1984; Waldhauser et al. 1985; Wurtman 1985).

Melatonin shows variation in the secretion synthesis during the course of ontogeny. In the postnatal period, as the nervous system matures in respect of its functions, an organism starts to form its own circadian rhythm of producing and releasing melatonin; this rhythm is not always consistent with the rhythm occurring in adult individuals (Attanasio et al. 1986; Horton et al. 1992; Kivela 1991; McMillen et al. 1989; Waldhauser et al. 1984).

Many problems concerning the biology of the pineal gland and the physiological role of melatonin have not yet been explained. In particular, the contribution of melatonin in regulatory processes of the biological rhythms is crucial both from the scientific and practical point of view. The above have prompted us to undertake an investigation aimed at determining the circadian changes in the melatonin level in the blood plasma of cows and calves and to describe character of these rhythms.

\section{Materials and Methods}

The experiment was performed using five. clinically healthy, Black and White bull calves, 2.5-month-old, and five Black and White cows in the seventh month of pregnancy. During the studies cows were kept in a litter barn with tying system of stalls and calves in the separated part of the same barn, under uniform conditions of environment. Cow's were fed rye and grass silage and concentrated feed mix. The feed ration was supplemented with hay and straw. The animals were allowed access to salt-lick and water. Calves were fed milk substituting preparation ( 71 per day). They were given free access to concentrated fodder. hay and water.

Before the experiment and during the whole study period were the animals maintained under LD 10:14 (light phase -5.30 to $15.30 \mathrm{~h}$. dark phase -15.30 to $5.30 \mathrm{~h}$ ).

The blood samples were drawn from the external jugular vein, nine times over a period of 24 , with 3-hour intervals, i.e.. at 15:00, 18:00, 21:00, 24:00, 3:00, 6:00, 9:00, 12:00 and 15:00 h. The collected blood was heparinized (Heparinum Polfa) and centrifuged immediately. The blood plasma was stored at $-20^{\circ} \mathrm{C}$ until analysed. When drawing blood samples in the dark phase, the red spot-lighting was used (with wavelength $>600 \mathrm{~nm}$ ).

Melatonin was determined by the radioimmunoassay (RIA) method (Arendt et al. 1977) with the use of the following reagents:

1. Melatonin. chromatographically pure (Sigma),

2. Melatonin. tritium-labelled (Amershman),

3. Norit A $0.4 \%$ activated carbon suspension with a $0.1 \%$ dextran addition.

4. Tricine $0.1 \%$ phosphate buffered solution. $\mathrm{pH} 7.7$,

5. Anti-melatonin antibodies received from CSIRO (Australia).

Determinations were made in $500 \mu \mathrm{l}$ of blood plasma. The calibration curve was prepared using the blood plasma of sheep, where endogenic melatonin was previously removed with the help of $4 \%$ activated carbon. The working dilution of antibodies was $300000 \times$. and the calibration curve range from 15.6 to $1000 \mathrm{pg} / \mathrm{ml}$.

The findings were statistically evaluated with the method of analysis of variance using the Duncan's D test (Statgraphics 5.0).

\section{Results and Discussion}

The results obtained in the experiment are presented in Tables 1 and 2. In all animals studied differences were observed between the melatonin level in the blood plasma in the light and the dark phase.

The mean hormone concentration in the dark phase in the blood plasma of cows was at the level of $218.75 \mathrm{pg} / \mathrm{ml}$. The highest concentration was obsereved at 18:00 and 3:00 h. It amounted to $234.8 \mathrm{pg} / \mathrm{ml}$ and $253.6 \mathrm{pg} / \mathrm{ml}$, respectively. The lowest mean values of the 
melatonin level in the dark phase was observed at 24:00 h. The mean concentration of melatonin in the light phase was $47.08 \mathrm{pg} / \mathrm{ml}$. The lowest hormone concentration in the blood was found by the end of this phase $(15: 00 \mathrm{~h})$. The amplitude of changes in the melatonin level in the blood between the light and the dark phase was $214.2 \mathrm{pg} / \mathrm{ml}$ (differences highly significant at $\mathrm{P}<0.01$ ). Similar differences in the melatonin concentration in the blood were found in cows by Newbold et al. (1991) and Berthelot et al. (1990; 1993).

Table 1

Melatonin levels in the blood plasma of cows $(n=5)$ in $\mathrm{pg} / \mathrm{ml}$

\begin{tabular}{|c|c|c|c|c|c|c|c|c|c|}
\hline Cow No & \multicolumn{10}{|c|}{ Time of sampling } \\
\hline & 1500 & 1800 & 2100 & 2400 & 300 & 600 & 900 & 1200 & 1500 \\
\hline 1 & 67 & 269 & 166 & 196 & 271 & 47 & 52 & 41 & 47 \\
\hline 2 & 40 & 254 & 302 & 133 & 348 & 47 & 70 & 33 & 30 \\
\hline 3 & 49 & 253 & 227 & 293 & 300 & 57 & 42 & 53 & 40 \\
\hline 4 & 40 & 128 & 114 & 118 & 179 & 109 & 41 & 50 & 43 \\
\hline 5 & 31 & 270 & 170 & 214 & 170 & 40 & 29 & 42 & 37 \\
\hline mean & 45.4 & $234.8^{*}$ & $195.8^{*}$ & $190.8^{*}$ & $253.6^{*}$ & 60.0 & 46.8 & 43.8 & 39.4 \\
\hline SD & 12.2 & 53.9 & 64.0 & 62.7 & 69.2 & 25.1 & 13.7 & 7.1 & 5.7 \\
\hline
\end{tabular}

Explanations:

dark phase

*significant differences between phases $(P<0.01)$

Table 2

Melatonin levels in the blood plasma of calves $(\mathbf{n}=5) \mathrm{in} \mathrm{pg} / \mathrm{ml}$

\begin{tabular}{|c|c|c|c|c|c|c|c|c|c|}
\hline Calf No & \multicolumn{10}{|c|}{ Time of sampling } \\
\hline & 1500 & 1800 & 2100 & 2400 & 300 & 600 & 900 & 1200 & 1500 \\
\hline 1 & 23 & 80 & 157 & 49 & 36 & 25 & 19 & 20 & 31 \\
\hline 2 & 16 & 308 & 297 & 195 & 309 & 36 & 40 & 24 & 27 \\
\hline 3 & 23 & 59 & 151 & 98 & 62 & 38 & 30 & 31 & 29 \\
\hline 4 & 24 & 29 & 99 & 41 & 44 & 36 & 29 & 41 & 27 \\
\hline 5 & 26 & 79 & 94 & 99 & 75 & 28 & 27 & 39 & 21 \\
\hline mean & 22.4 & $111.0^{*}$ & $159.6^{*}$ & $96.4^{*}$ & $105.2^{*}$ & 32.6 & 29.0 & 31.0 & 27.0 \\
\hline SD & 3.8 & 112.0 & 82.1 & 61.3 & 114.9 & 5.7 & 7.5 & 9.1 & 3.7 \\
\hline
\end{tabular}

Explanations:

dark phase

*significant differences between phases $(P<0.01)$

The findings presented here point out that cows have a type of the night production of melatonin that is characterized by an increased secretion of the hormone shortly after the beginning of the dark phase, its high and not always stable level during this phase, and a rapid decrease of its level prior to the light phase.

Nowak et al. (1990) found a similar profile of changes of the melatonin level in the blood plasma of sheep. Significant differences in the daytime and overnight melatonin levels were 
found in adult humans. The concentration of melatonin ranged from 0 to $40 \mathrm{pg} / \mathrm{ml}$ in the light phase, and from 50 to $200 \mathrm{pg} / \mathrm{ml}$ in the dark phase (Waldhauser et al. 1983). Similar findings are reported by Grof et al. (1985). However. the night type of the melatonin production in humans is different.

In the presented experiment an individual variation of the melatonin level in the blood of cows was shown. The concentration of melatonin in the light phase ranged from 31 to 109 $\mathrm{pg} / \mathrm{ml}$. while in the dark phase from 114 to $348 \mathrm{pg} / \mathrm{ml}$.

The mean hormone concentration in the blood plasma of calves in the dark phase was $118.5 \mathrm{pg} / \mathrm{ml}$. In four calves studied the melatonin level increased slowly after the beginning of the dark phase. with its highest level occurring between 21:00 and 24:00 h. One calf displayed the same profile of changes of the melatonin concentration in the blood plasma as was found in adult cows. The results obtained point to significant individual differences in the melatonin concentration in the blood plasma of calves, in particular in the dark phase of the circadian cycle.

The mean level of melatonin in calves in the light phase was $28.4 \mathrm{pg} / \mathrm{ml}$. The lowest concentration in the blood was found by the end of the light phase $(15: 00 \mathrm{~h})$ similar to that found in cows. The amplitude of changes in the melatonin level in the blood between the light and dark phase was $89.65 \mathrm{pg} / \mathrm{ml}$ (differences highly significant at $\mathrm{P}<0.01$ ).

These findings point out that the overnight production of melatonin in calves represents a different profile than that of adult individuals characterized by a smooth increase in the melatonin secretion after the beginning of the dark phase and an equally smooth decrease of its level in the second half of this phase.

Hedlund et al. (1977), in their studies on 9-month-old calves, showed a similar profile of the night production of melatonin. too. In calves, according to them, there is only one night peak in the melatonin production at $3: 00 \mathrm{~h}(220 \mathrm{pg} / \mathrm{ml})$. A similar profile occurs in many other species, among others in rat, squirrel, hen and man.

It was also shown in the present studies that the mean level of melatonin in the blood plasma of calves was nearly two times lower than that of cows, both in the light phase (28.4 and 47.08 $\mathrm{pg} / \mathrm{ml}$. respectively) and in the dark one ( 118.05 and $218.75 \mathrm{pg} / \mathrm{ml}$, respectively).

As it appears from the results presented here, the production of melatonin in the pineal gland and its blood level are subject not only to the circadian changes but show variation in the course of ontogeny. An organism in the early postnatal period starts, in all probability in the connection with maturation of the nervous system being intermediary in synchronizing biological rhythms with changes in the environmental conditions, especially light and temperature, to form its own circadian rhythm of the melatonin secretion which is not alwyas the same as in adults in respect of its cycle and amplitude.

Waldhauser et al. $(1984 ; 1985)$ found, studying the melatonin level in humans, that the concentration of this hormone in the blood plasma in children during daytime was low (below $20 \mathrm{pg} / \mathrm{ml}$ ) and did not change with age. The overnight concentration of melatonin in children $1-5$ years old is several times higher (about $200 \mathrm{pg} / \mathrm{ml}$ ) than in juveniles and adults (about $50 \mathrm{pg} / \mathrm{ml}$ ). Similar findings are given by Wurtman (1985).

When interpreting the results obtained in the studies one should consider the effect of pregnancy on the level and profile of the melatonin production. It is known from the literature that in the late pregnancy in humans (Kivela 1991; Maggioni et al. 1992), also in cows (Newbold et al. 1991), sheep (Hougton et al. 1993; Lee et al. 1993) and rats (Velasquez et al. 1978), the melatonin level in the blood is higher than in nonpregnant individuals. Most authors report, however, that the circadian profile of secretion of this hormone is constant over the whole pregnancy period. Kivela (1991) is of the opinion that an increase in the melatonin concentration during pregnancy does not result from the 
increased secreting activity of the pineal gland of foetus. On the other hand, it was confirmed (McMillen et al. 1989) in the studies on pregnant sheep and their foetuses that melatonin being present in the blood of foetuses does not come from their own pineal body but passes with the blood through placenta from their mothers.

In conclusion, the melatonin concentration in the blood of pregnant cows and calves showed highly significant differences $(\mathrm{P}<0.01)$ during the light and the dark phase. The profile of the melatonin production in the dark phase varied in the course of ontogeny. The melatonin level in the blood of pregnant cows and calves showed high individual variations during the circadian cycle. The melatonin level in the blood of calves was significantly lower $(\mathrm{P}<0.01)$ than in the blood of pregnant cows, both in the light and in the dark phase.

\section{Cirkadiánní změny koncentrace melatoninu v krvi březích krav a telat}

Cirkadiánní změny koncentrace melatoninu $\mathrm{v}$ krvi březích krav a telat byly sledovány $\mathrm{u}$ skupiny březích krav a u 2,5 měsíčních telat. Před pokusem a během pokusu byla zvírata ustájena v prostředí se stejným režimem střídání světla a tmy (LD 10:14). Krevní vzorky byly odebrány z v. jugularis externa 9 krát během 24 h, v 15,00;18,00;21,00;24,00;3,00; 6,$00 ; 9,00 ; 12,00 ;$ a v $15,00 \mathrm{~h}$. Melatonin byl stanoven radioimunoenzymatickou metodou (RIA). Výsledky byly analyzovány pomocí Duncanova $\mathrm{D}$ testu.

Vysoce významné rozdíly ( $\mathrm{P}<0,01)$ koncentrace melatoninu byly zaznamenány při stř́ídání světla a tmy u krav i u telat. U telat byla koncentrace tohoto hormonu v krvi v obou fázích významně nižší $(\mathrm{P}<0,01)$ než u krav. Rovněž se lišila produkce hormonu u krav a telat $v$ noci. Prokázali jsme tak, že syntéza melatoninu a jeho uvolňování ve tmě je ovlivněno věkem.

\section{References}

ARENDT. J.. WETTERBERG, L., HEYDEN. I., SIZONENKO, P. C.. PAUNIER. L. 1977: Radioimmunoassay of melatonin in human serum and cerebrospinal thuid. Horm. Res. 8: 65-69

ATTANASIO. A.. RAGER. K.. GUPTA. D. 1986: Ontogeny of circadian rhy thmicity for melatonin. serotonin and N-acetylserotonin in humans. J. Pineal Res. 3: 251-256

BERTHELOT. X.. LAURENTIE, M.. RAVAULT. J. P., FERNEY. J.. TOUTAIN. P. L. 1990: Circadian profile and production rate of melatonin in the cow. Anim. Endocr. 7: 315-322

BERTHELOT. X.. RAVAUlT, J. P.. CONCORDET. D.. FERNEY. J., TOUTAIN. P. L. 1993: Absence of circadian rhythm in the disposition of melatonin in the cow. J. Pineal.Res. 15: $1+1-1+6$

BINKLEY.S. A. 1979: A time-keeping enzyme in the pineal gland. Sci. Am. 240: $50-55$

CYMBOROWSKI. B.. DUTKOWSKI. A. 1969: Circadian changes in RNA synthesis in the neurosecretory cells of the brain and the suboesophageal ganglion of the house cricket. J. Insect Physiol. 15: 187-191

DEGUCHI. T. 1979: A circadian oscilatoring cultured cell of chicken pineal gland. Nature 282: 94-96

GROF. E., GROF. P.. BROWN. G. M.. ARATO. M.. LANE. I. 1985: Investigations of melatonin secretion in human. Neuro-Psychopharmacol. Biol. Psychiatry. 9: 609-612

HASEGAWA. A.. OHTSUBO. K.. IZUMIYAMA. N.. SHIMADA. H. 1980: Ultrastructural study of the human pineal gland in aged patiens including a centenarian. Acta Pathol. Jpn. 40: 30-40

HEDLUND. L.. LISCHKO. M. M.. ROLLAG. M. D.. NISWENDER. G.D. 1977: Melatonin: Daily cycle in plasma and cerebrospinal thuid of calves. Science 195: 686-687

HORTON, T. H., RAY. S. L.. ROLLAG, M. D., YELLON. S. M.. STETSON. M. H. 1992: Maternal transfer of photoperiodic information in siberian hamsters. Effects of melatonin implants are dependent on photoperiod. Biol. reprod. 47: 297-296

HOUGTON. D. C.. WALKER. D. W.. YOUNG. I. R.. McMILlEN. I. C. 1993: Melatonin and the Light - Dark cycle separately influence daily behavioral and hormonal rhythms in the ewe and sheep fetus. Endocrinology 133: $90-98$

KIVELA. A. 1991: Serum melatonin during human pregnancy. Acta Endocrinol. 124: 233-237

KLEIN. D. C. 1979: Circadian rhythms in the pineal gland. In: Endocrine rhythms. Ed.: Krieger D.T., Raven Press, New York. pp. 203-233 
KLEIN, D. C., ROSEBOOM, P. H.. COON. S. L. 1996: New light is shining on the melatonin rhythm enzyme. The Metab. 7: 106-112

LEE. J. M.. STORMSHAK. F. THOMSON. J. M.. THINESEN. P.. PAINTER. L. J.. OLENCHEK. E. G.. HESS, D. L.. FORBES, R.. FOSTER. D. L. 1993: Melatonin secretion and puberty in female lambs exposed to environmental electric and magnetic fields. Biol. reprod. 49: 857-864

MAGGIONI, C., ANTINOZZI. R.. BERTACCA, S., CARLLCCI, C., BENZI, G. 1992:Melatonin circadian rhythm hormonal phases relation during human pregnancy. Melatonin and the pineal gland from basic science to clinical application. Satellite Symposium of the IX International Congress of Endocrinology: Paris, 133 p.

MALLO, C., ZAIDAN. R.. GALY. G., VERMEULEN. E., BRLN. J.. CHAZOT. G.. GLAUSTRATS. B. 1990: Pharmacokinetics of melatonin in man after intravenous infusion and bolus infection. J. Clin. Pharmacol. 38: 297-301

MCMILLEN, I. C., NOWAK, R. 1989: Maternal pinealectomy abolishes the diurnal rhythm in plasma melatonin concentrations in the fetal sheep and pregnant ewe during late gestation. J. Endocr. 120: 459-464

NEWBOLD, J. A.. CHAPIN. L. T., ZINN. S. A.. TUCKER. H. A. 1991: Effects of photoperiod on mammary development and concentration of hormones in serum of pregnant dairy heifers. J. Dairy Sci. 74: 101-108

NOWAK, R., RAJKUMAR. R. R.. WEBLEY. G. E., RODWAY. R. G. 1990: Effect of prolonged exposure to exogenous melatonin on the onset and end of the breeding season and on the growth rate of ewe lambs. Br. Vet. J. 146: 17-23

REITER, R. J. 1991: Pineal melatonin: cell biology of its synthesis and of its physiological interactions. Endocr. Rev. 12: $151-180$

WALDHAUSER, F.. WURTMAN. R. J. 1983: The secretion and actions of melatonin, In: Biochemical actions of hormones. Academic Press, New York. pp. 187-195

WALDHAUSER, F., WEISSENBACHER, G., ZEITHUBER. U., WALDHAUSER, M., FRISCH, H., WURTMAN. R. J. 1984: Fall in nocturnal serum melatonin levels during prepuberty and pubescence. Lancet 362-365

WALDHAUSER. F.. DIETZEL. M. 1985: Daily and annual rhythms in human melatonin secretion. role in puberty control. Ann. N.Y. Acad. Sci. 453: 205-214

VELASQUEZ, E., ESQUIFINO. A. J., ANTONIO-ZWECO. J., RUIZ-ALBUSAC, J. M.. BLAZQUES, E., ZWECO, J. A., ALBUSAC, J.. RUIZ, M. 1978: Evidence that circadian variations of circulating melatonin levels in fetal and suckling rats are dependent on maternal melatonin transfer. Neuroendocr. 55: 289-310

WURTMAN R. J. 1985: Melatonin in humans. Proc. of the First Int. Congress on Melatonin in Humans. Vienna. pp. 1-8 